\title{
Economic growth and inequality of income distribution between regions: Evidence from Bali Province, Indonesia
}

\author{
Dewa Putu Sudibya Sukmaadi* and Anak Agung Istri Ngurah Marhaeni \\ Faculty of Economics and Business, Udayana University, Denpasar, Bali, Indonesia \\ *Correspondence email: dwsudibya@gmail.com
}

\section{ARTICLE INFO}

- Research Article

Article History

Received 17 October 2020

Accepted 8 December 2020

Published 1 April 2021

\section{Keywords}

education; government expenditure; health; infrastructure; locallygenerated revenue

\section{JEL Classification} E27; H75; R58

\begin{abstract}
Bali Province shows a prominent performance in the development of the tourism sector. However, essential problems were found related to inequality in the distribution of income between regions. The aim of this study was to analyze the effect of locally-generated revenue, education spending, health spending, investment and infrastructure on economic growth and inequality in income distribution between regencies and cities in Bali province. This study used a quantitative approach. The study explored panel data that combined time series and cross section data from the Regency/City of Bali Province during 2010 2017. The data analysis method used was path analysis. The results showed that local revenue, education spending, government spending on health, investment, and infrastructure have a positive effect on economic growth and reduced income inequality between regions. Economic growth is also able to mediate the influence of variables on inequality. The findings of this study emphasize the importance of planning coordination from each district and city to mutually commit in mobilizing all local resources such as human resources, finance, investment and infrastructure; to generate economic growth and reduce inequality between regions.
\end{abstract}

To cite this article: Sukmaadi, D. P. S. \& Marhaeni, A. A. I. N. (2021). Economic growth and inequality of income distribution between regions: evidence from Bali Province, Indonesia. Journal of Socioeconomics and Development, 4(1), 69-80. https://doi.org/10.31328/jsed.v4i1.1676

ISSN 2615-6075 online; ISSN 2615-6946 print (C)WG Press, 2021

\section{INTRODUCTION}

Indonesia's economic development in accordance with the mandate in the Preamble to the 1945 Constitution is to create a just and prosperous society. This is achieved through economic development policies with the main target of reducing poverty, income inequality, and the unemployment rate. Development is also directed at creating employment opportunities for residents in various regions in a sustainable manner. The economic growth is not the only main goal of development efforts, but it reaches out to socio-economic development, equitable development, and eliminates inequality.

Poverty and inequality are at the core of general economic development problems (Arsyad, 2010). Poverty alleviation and income inequality are currently the main problems in development in many countries. Inequality between regions is a common aspect including poor countries, developing countries, and even developed countries. Inequality between regions is caused because each region has differences in resources, labor, and technology (Berg \& Ostry, 2017; Chen \& Groenewold, 2019). 
The relationship between income inequality and economic growth and related issues has been extensively researched in the literature. A typical study is that of Barro (2000); Forbes (2000), followed by various other studies (Fawaz, Rahnama, \& Valcarcel, 2014; Hong Vo, Van Nquyen, Minh Nquyen, The Vo, \& Cong Nguyen, 2020; Huang, Fang, Miller, \& Yeh, 2015; Madsen, Islam, \& Doucouliagos, 2018; Wahiba \& Weriemmi, 2014).

Kuznet (1955) and Berg \& Ostry (2017) emphasized that inequality is a consequence of economic growth. Thus, inequality increases at the early stages of the economic development process before decreasing with later stages of development. Since then, most studies related to inequality and economic growth have been conducted and show a positive relationship (Lundberg \& Squire, 2003; Rubin \& Segal, 2015; Wahiba \& Weriemmi, 2014) while some analyzes support a negative relationship (Majumdar \& Partridge, 2009; Nissim, 2007). Several studies also offer mixed results (Chambers, 2010; Huang et al., $\underline{2015}$ ).

The awareness that income inequality affects economic growth has been considered, along with the findings of Kuznets (1955). Various studies have investigated whether inequality contributes to economic growth and have revealed a positive relationship (Forbes, 2000; Li \& Zou, 1998) or a negative relationship (Cingano, 2014; Wahiba \& Weriemmi, 2014). For instance, Fawaz et al. (2014) confirmed the negative impact of income inequality on economic growth in low-income developing countries.

Bali Province is an area known as a tourism destination, where the tourism sector is the backbone of economic growth in Bali Province. The development of tourism in Bali has made the structure of the Balinese economy experience a shift from primary to tertiary. The sector of providing accommodation, food, and beverage, which is the sector with the largest linkage to tourism, and gives the most dominant contribution to the GRDP of Bali Province.

Urban areas continue to display higher economic growth as potential resources continue to shift to developed regions as growth centers with higher economic growth. This condition in turn causes growth centers to experience accumulated growth, supported by the potential of migratory resources. If a region is unable to compete to keep up with regions with high economic growth, this can result in the unequal distribution of income between regions. Therefore, planned and oriented development efforts to reduce inequality of income distribution between regions is very important.

Table 1. Williamson Index in Bali Province, in 2013-2019

\begin{tabular}{|c|c|c|c|c|c|c|c|}
\hline Regency/City & 2013 & 2014 & 2015 & 2016 & 2017 & 2018 & 2019 \\
\hline Jembrana & 0.11 & 0.11 & 0.10 & 0.10 & 0.10 & 0.13 & 0.13 \\
\hline Tabanan & 0.08 & 0.07 & 0.07 & 0.06 & 0.06 & 0.08 & 0.08 \\
\hline Badung & 0.55 & 0.54 & 0.52 & 0.51 & 0.51 & 0.62 & 0.61 \\
\hline Gianyar & 0.02 & 0.02 & 0.01 & 0.01 & 0.01 & 0.04 & 0.04 \\
\hline Klungkung & 0.12 & 0.13 & 0.12 & 0.11 & 0.11 & 0.13 & 0.13 \\
\hline Bangli & 0.47 & 0.47 & 0.47 & 0.46 & 0.46 & 0.47 & 0.47 \\
\hline Karangasem & 0.30 & 0.30 & 0.29 & 0.29 & 0.29 & 0.30 & 0.30 \\
\hline Buleleng & 0.08 & 0.07 & 0.06 & 0.06 & 0.06 & 0.08 & 0.08 \\
\hline Denpasar & 0.05 & 0.05 & 0.04 & 0.03 & 0.03 & 0.01 & 0.01 \\
\hline Bali province & 0.14 & 0.13 & 0.12 & 0.10 & 0.10 & 0.16 & 0.15 \\
\hline
\end{tabular}

Source: Author's calculation

Inequality in income distribution between regions occurs due to the high concentration of economic activity in certain areas (Berg \& Ostry, 2017). The process that causes inequality is very complex, influenced by differences in economic growth, regional financial capacity, investment allocation, infrastructure availability, the quality of human resources in a region (Bappenas, 2014; Tambunan, 2007; Rahmawati et al., 2020). The occurrence of inequality between regions is caused by differences in resources, differences in demographic conditions, less smooth mobility of goods and services, the concentration of regional economic activities, and allocation of development funds between regions.

The greater the inequality figure indicates that the distribution of income between regions is not even. Badung, Bangli, and Karangasem regency have high inequality rates when compared to the inequality rate in Bali Province (Table 1). This is a problem that needs to be resolved immediately, so it is not to cause 
widespread negative impacts. Investment in Bali Province is very dominant in developed areas such as Denpasar City and Badung Regency. The amount of investment in this area cannot be separated from the influence of the tourism sector, which is the backbone of the economy in the area.

Investments in Bali Province are predominantly carried out in developed areas such as Denpasar City and Badung Regency. The amount of investment is inseparable from the tourism sector activity which is the backbone of the economy in the area. In general, the tourism sector provides a major contribution to the economy in Bali Province, especially in these three areas. This flow of investment or economic activity has resulted in other regions not getting the results of development and they becomes underdeveloped regions.

Investors' reluctance to invest in other sectors such as agriculture makes it difficult for other districts to compete with the three regions in attracting investment. Research conducted by Danawati et al. (2016) stated that investment has a positive and significant effect on the economic growth of regencies/cities in Bali Province. This shows that increased investment will increase economic growth. According to Samuelson \& Nordhaus (2006), investment is needed as a supporting factor to improve the production process.

Efforts to reduce inequality are carried out by accelerating development in disadvantaged areas (Elia et $\mathrm{al}, 2020)$. One important aspect of the implementation of regional autonomy authority is to strengthen the level of regional independence and increase the potential for regional income to finance government administration and development activities (Enceng, Irianto, \& Purwaningdyah, 2014). Regional financial independence can be measured from the receipt of Locally Original Revenue (PAD) against total regional income. PAD is a source of local revenue originating from local taxes, local levies, BUMD products and other legitimate local revenue. Increasing PAD will provide flexibility to local governments to provide the best services for the community and develop new economic potential.

One of the causes of inequality between regions is the difference in the quality of human resources. Government spending on education and health is the government's effort to improve the quality of human resources in the regions. According to Garcia \& Soelistianingsih (1998), education is needed to reduce regional inequality and health is needed to optimize all the potential that the community has in order to be able to make a positive contribution to the regional economy. Investment is the accumulation of capital that can later be used to boost the economy of a region. According to Zulyanto (2010), increased investment will increase revenue multipliers in the regions. It is hoped that increased investment in underdeveloped areas will boost the economy in these areas so that inequality between regions can be reduced. Infrastructure is the main support in the implementation of business processes, development, and projects (Berg \& Ostry, 2017; Chen \& Groenewold, 2019). Infrastructure is an important element in the development of a region because infrastructure facilitates and integrates economic activities. The study by Maryaningsih et al. (2014) stated that the provision of basic infrastructures such as the availability of quality roads and access to remote areas has a positive impact on economic development in these areas.

The relative availability of infrastructure in the Denpasar and Badung regions is relatively better compared to other areas in Bali Province which is also a driving force for investment in these regions (Danawati et al., 2016). This shows that the efforts of local governments to direct investment more fairly have not shown optimal results. If this happens in the long term, the existing regional income gap will widen in Bali Province. Economic activity in Bali Province shows serious imbalances. Economic activities in Bali Province are mostly concentrated in the southern part of Bali Island.

Inequality in the availability of infrastructure can lead to disparities between regions (Chen \& Groenewold, 2019). The right infrastructure functions to encourage various economic activities, streamline the production process and the mobility of people, goods and services. Equitable road infrastructure will improve the smooth mobility of goods and services to support regional economic activities. The road density ratio shows the level of accessibility between regions. The greater the road density ratio reflects the ease of reach between areas connected to road infrastructure in region and vice versa.

Maryaningsih et al. (2014) stated that the availability of adequate road conditions both in quality and quantity is one way to achieve sustainable economic growth. It is hoped that the improvement in the quality and quantity of road infrastructure in 
underdeveloped areas will have a positive impact on economic development in these areas to spur economic growth.

This study aims to study the effect of local revenue, government spending on education and health, investment, and infrastructure on the inequality of income distribution between regencies/ cities in Bali Province.

\section{RESEARCH METHOD}

The research elaborated on the regencies and cities data in Bali Province, Indonesia. There were indications of regional imbalances in Bali region as shown by Williamson index numbers in several regencies. This research is quantitative research, with the research design aims to explain the relationship between the differences or the influence of one variable with another. This study used panel data which is a combination of time series and cross-section data. By accommodating information related to both cross-section and time-series variables, panel data can substantially reduce the problem of omitted-variables, a model that ignores relevant variables (Gujarati, 2004). This research was conducted in the regencies/cities of Bali Province for the period from 2010 - 2017.

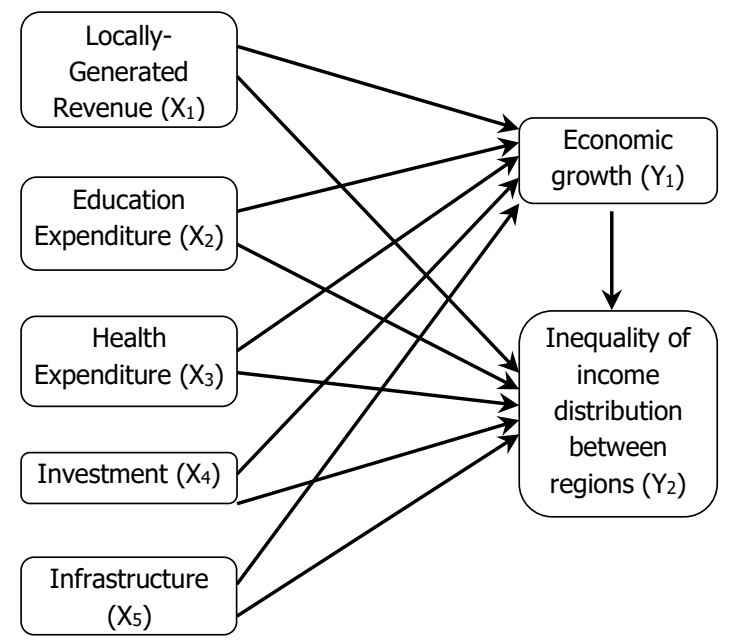

Figure 1. Relatonship between variables

The selection of variables is motivated by efforts to reduce the inequality between regions by reducing the distance between the richest and poorest regions, through special efforts to significantly elevate the poorest regions (Bappenas, 2010). The variables include locally-generated revenue (PAD), government spending in the education and health sector, investment (from domestic and foreign), road infrastructure, economic growth, and inequality between regions (measured using the Williamson index). The relationship between variables presented in Figure 1 and Equations 1 and 2.

$$
\begin{aligned}
Y_{1}=\beta_{1} X_{1}+\beta_{2} X_{2}+\beta_{3} X_{3}+ & \beta_{4} X_{4}+\beta_{5} X_{5}+e_{1} \ldots(1) \\
Y_{2}=\beta_{6} X_{1}+\beta_{7} X_{2}+\beta_{8} X_{3}+ & \beta_{9} X_{4}+\beta_{10} X_{5}+ \\
& \beta_{11} Y_{1}+e_{2}
\end{aligned}
$$

in which $Y 1, Y 2, X 1 . .5$, are variables (Figure 1 ); $\beta_{1 . .11}$, is coefficient; $e 1, e 2$ is error.

The data analysis technique used in this study was Path Analysis, which was analyzed using Smart PLS software. The choice of path analysis is based on the consideration that the form of the causal relationship and form of relationship of simultaneous systems.

\section{RESULT AND DISCUSSION}

\section{Inequality in Bali Province}

Efforts to increase PAD are carried out as much as possible to realize the spirit of regional independence. Realization of PAD regencies/cities in Bali Province during the period 2010 to 2017 continued to increase (Figure 2 and Table 2). Badung Regency is the district with the highest PAD in Bali Province, sourced from tax revenue especially from hotel and restaurant taxes as the main economic activity.

Education is one of the determining factors for the quality of human resources which will later contribute to development in an area. The government should prioritize the education sector by allocating spending on education. District and municipal education spending in Bali Province has fluctuated. In several regions, government spending on education has decreased. This decline was likely caused by weak coordination between budget planning and implementation which resulted in low budget absorption.

The health sector is an important part in efforts to improve the quality of human life. Fulfilling health need by the government is one of the provisions to meet basic needs. Without health, an area cannot generate productivity. Economic activities will run if there is certainty about health insurance for the community. 

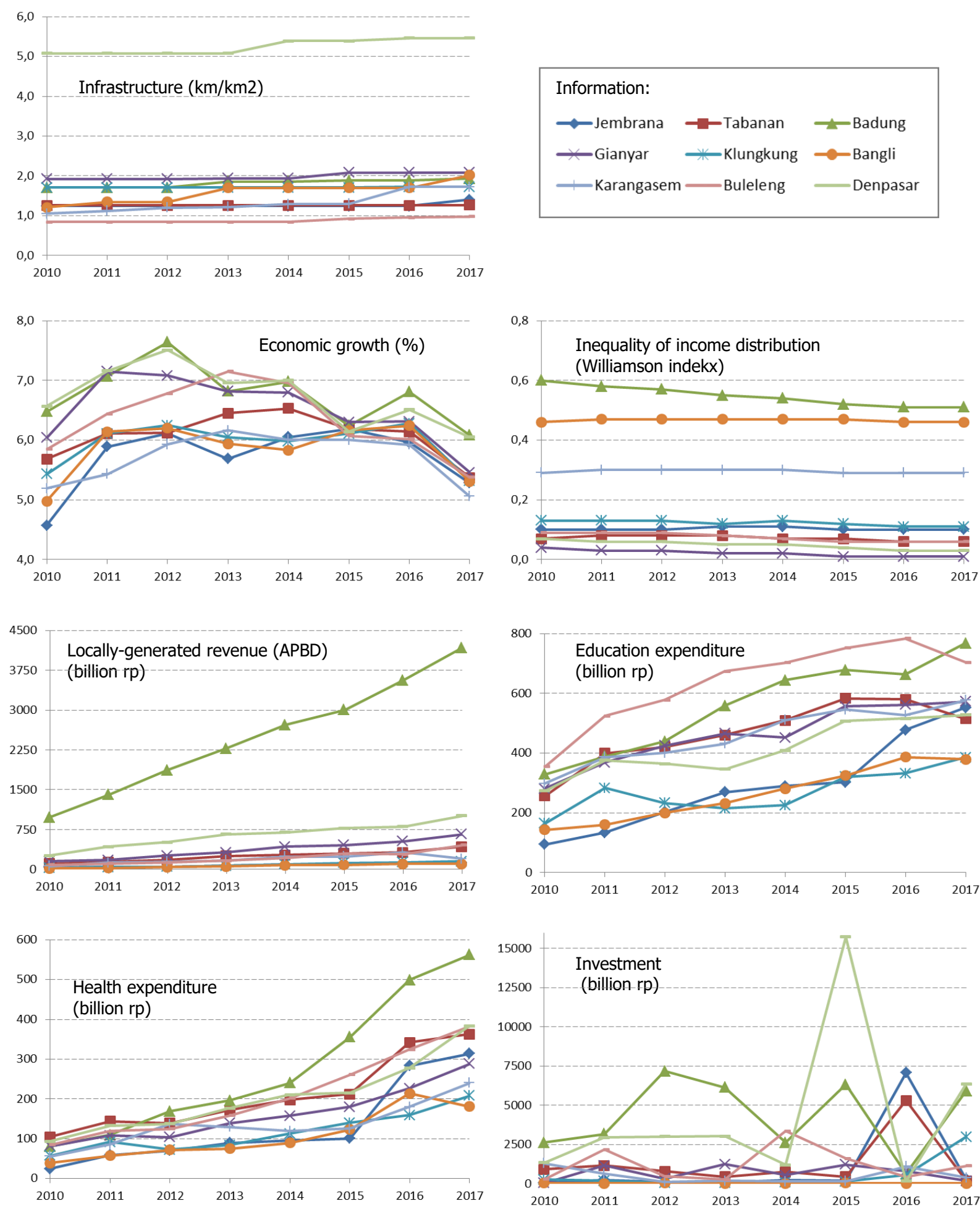

Figure 2. Variables related to inequality between region in Bali Province, 2010-2017 
District and municipal health sector spending in Bali Province from 2010 to 2017 shows various developments. Regions such as Tabanan, Gianyar, Klungkung, and Karangasem districts show a decline in government spending on health. In 2012, there was a decline in health sector financing but then increased in subsequent years. Meanwhile, health spending in Karangasem Regency has decreased in a row, namely 2013 and 2014.

Investment is important in economic development to support an increase in the production process. The investment ensures that the community continues to increase economic activity, employment opportunities, national income, and the level of community welfare. Investment also encourages capital accumulation. The addition of the stock of buildings and other important equipment will increase the potential output of a nation and promote long-term economic growth.

The highest investment occurred in 2015 in Denpasar City with a value of 15.7 trillion rupiahs (Figure 2), on the other hand, the lowest investment was in Bangli Regency at $\mathbf{3 0 . 7}$ billion rupiahs. Bangli Regency has always received the lowest investment value during the period 2010 to 2017. There is a tendency for investment in southern Bali to have a relatively high attractiveness. This cannot be separated from the activities of the tourism sector which are concentrated in the area.

Road is important infrastructure to support transportation, which has a strategic function to connect one area to another. Road infrastructure development has an accessibility function to open up disadvantaged areas and a mobility function to spur developed regions. The availability of infrastructure and other facilities in southern Bali is better than in the northern part. Thus, it can provide a significant incentive to invest in economic activity.

The development of the road density ratio in regencies and cities in Bali Province has increased. In 2017 the highest road density ratio was in Denpasar, namely $5.46 \mathrm{~km}$ per $\mathrm{km} 2$; and the lowest was in Buleleng Regency, namely $0.98 \mathrm{~km}$ per km2. Buleleng Regency is dominated by hilly areas. This causes road infrastructure development to experience and obstacles more.

The economic growth of regencies and cities in Bali Province varies. All districts and cities in Bali Province show fluctuating economic growth. The highest economic growth occurred in Badung Regency in 2012, namely 7.64 percent and the lowest economic growth occurred in Jembrana Regency in 2010, namely 4.57 percent. From 2010 to 2017 Bangli Regency had the lowest economic growth, namely, 5.70 percent, and Denpasar City had the highest economic growth, namely 6.74 percent.

The Williamson index for districts and cities in Bali Province is varied and relatively low. The higher the index, the higher the inequality of income distribution in a region. Income inequality between regions occurs due to the high concentration of an economic activity in certain areas. This has resulted in many regions not getting economic benefits so that they become underdeveloped regions. In general, the tourism sector provides a major contribution to the economy in Bali Province, especially in Badung, Gianyar, and Denpasar City Regencies.

\section{Economic Growth and Inequality}

The results showed that PAD had a positive and significant effect on the economic growth and inequality of income distribution of regencies/cities in Bali Province (Table 3 and 4). Table 3 indicates a direct relationship between $P A D$ and economic growth. Generally, PAD in all regions in Bali Province has increased so that it has an impact on increasing economic growth. This finding is consistent with the results of Bratakusumah (2001) which states that PAD has a positive effect on economic growth in the regions. PAD also shows a negative and significant effect on the inequality of income distribution between regencies/cities in Bali Province (Table 4). The increasing PAD causes the inequality reduction of the income distribution. This is in line with a research conducted by Nurhuda (2013) which revealed that PAD has affected inequality reduction in 38 regencies and cities in East Java Province.

Regions with high PAD growth tend to have higher per capita income. One of the main objectives of fiscal decentralization is the creation of regional independence so that local government can explore regional financial sources and strengthen local revenue. High PAD will be used to finance regional development expenditures which will ultimately increase regional economic growth (Tambunan, 2007), and also reduce economic inequality among regions. 
Table 2. Variables Related to Inequality between Region in Bali Province in 2017.

\begin{tabular}{|c|c|c|c|c|c|c|c|}
\hline Regency/City & $\begin{array}{l}\text { Locally- } \\
\text { Generated } \\
\text { Revenue }\end{array}$ & $\begin{array}{c}\text { Education } \\
\text { expenditure }\end{array}$ & $\begin{array}{c}\text { Health } \\
\text { Expenditure }\end{array}$ & Investment & $\begin{array}{l}\text { Road Infra- } \\
\text { structure }\end{array}$ & $\begin{array}{l}\text { Economic } \\
\text { growth }\end{array}$ & $\begin{array}{l}\text { Inequality of } \\
\text { income } \\
\text { distribution } \\
\text { between } \\
\text { regions }^{1}\end{array}$ \\
\hline & \multicolumn{4}{|c|}{ } & $\mathrm{km} / \mathrm{km} 2$ & $\%$ & \\
\hline Jembrana & 121.34 & 551.92 & 313.81 & 276.07 & 1.40 & 5.28 & 0.10 \\
\hline Tabanan & 426.64 & 514.62 & 362.71 & 189.99 & 1.27 & 5.37 & 0.06 \\
\hline Badung & 4172.46 & 767.28 & 562.02 & 5910.93 & 1.93 & 6.08 & 0.51 \\
\hline Gianyar & 662.75 & 572.33 & 288.56 & 186.99 & 2.08 & 5.46 & 0.01 \\
\hline Klungkung & 153.21 & 385.23 & 208.25 & 2980.99 & 1.72 & 5.32 & 0.11 \\
\hline Bangli & 104.59 & 379.46 & 180.98 & 26.45 & 2.02 & 5.31 & 0.46 \\
\hline Karangasem & 198.58 & 576.13 & 240.48 & 393.88 & 1.72 & 5.06 & 0.29 \\
\hline Buleleng & 455.20 & 703.69 & 382.69 & 1126.41 & 0.98 & 5.38 & 0.06 \\
\hline Denpasar & 1008.71 & 527.06 & 383.37 & 6366.39 & 5.46 & 6.05 & 0.03 \\
\hline
\end{tabular}

${ }^{1}$ measured by Williamson index

Table 3. Variable Affecting Economic Growth of Regions in Bali Province

\begin{tabular}{lrrr}
\hline Variable & $\begin{array}{r}\text { Coeffi- } \\
\text { cient }\end{array}$ & t & p value \\
\hline (Constant) & 1.923 & 2.246 & 0.025 \\
Locally-generated revenue & 0.231 & 2.598 & 0.012 \\
Education expenditure & 0.715 & 2.410 & 0.019 \\
Health Expenditure & 0.700 & 3.373 & 0.001 \\
Investment & 0.628 & 4.851 & 0.000 \\
Infrastructure & 0.126 & 2.223 & 0.030 \\
\hline
\end{tabular}

Table 4. Variable Affecting Inequality of Income Distribution of Regions in Bali Province

\begin{tabular}{lrcr}
\hline Variable & $\begin{array}{r}\text { Coeffi- } \\
\text { cient }\end{array}$ & t & p value \\
\hline (Constant) & 3.536 & 2.695 & 0.009 \\
Locally-generated revenue & -0.167 & -6.897 & 0.000 \\
Education expenditure & -0.239 & -2.343 & 0.031 \\
Health Expenditure & -0.138 & -2.310 & 0.024 \\
Investment & -0.041 & -2.745 & 0.028 \\
Infrastructure & -0.054 & -3.429 & 0.001 \\
Economic growth & -0.040 & -4.634 & 0.000 \\
\hline
\end{tabular}

Education is a vital component to contribute to economic growth. Huang et al. (2015) and Li \& Zou (1998) stated that spending on the education sector has a positive impact on economic growth. This finding implies that an increase in government spending on education has proven capable of driving economic growth (Elia et al, 2020).

Government spending on education has a negative and significant effect on inequality in income distribution between regions. Income inequality between regions can be caused by the quality of human resources. Low-quality of human resources are neither unable to produce progress in economic development nor develop the potential for creating new economic activities. Therefore, education spending needs to be optimized to encourage improvement in the quality of human resources. Education is an approach to uplifting human dignity and achieving social and economic welfare. Education at all levels will increase people's income and economic productivity. According to Schweke (2015), education will not only produce quality human resources (HR), knowledge, and skills in the use of technology but it can also foster a healthy business climate to support economic growth.

Government spending in the health sector has a positive and significant effect on the economic growth and income inequality between districts and cities in Bali Province for the period 2010 - 2017. Government spending in the health sector will increase the coverage of health services so that the quality of public health is more secure and better. Better health will support people to be more productive and live longer so that economic activities will increase. With increasing longevity, savings and investment in education and pensions increase. This will attract a higher investment in health. This leads to the accumulation of capital, which in turn leads to the efficiency of the aggregate economy and an increase in the level of economic activity (Aísa \& Pueyo, 2006; Cervellati \& Sunde, 2011; Lopez-Casasnovas et al., 2005). Furthermore, an increase in spending in the health sector will reduce inequality in income distribution, as the study by Ospina (2014) of similar findings in Latin American countries.

Bloom et al. (2004) found that improving health increases output not only through labor productivity but also through capital accumulation. There is a positive impact of health and health spending on the 
economy. There are four ways in which health affects economic growth. This increases labor productivity, creates a greater supply of labor, acts as a catalyst for skills-boosting education and training, and saves more savings for investment in physical and intellectual capital. Bloom \& Canning (2008) further revealed that health also affects life expectancy and life cycle behavior. Insofar as income is a health consequence, investment in health is a priority. The argument for health as an investment is particularly relevant because inexpensive and easy-to-implement health policies can dramatically improve health.

The results showed that the infrastructure variable had a positive and significant effect on the economic growth and inequality in income distribution between regions. Investment is needed as a supporting factor in improving the production process (Danawati et al., 2016; Samuelson \& Nordhaus, 2006). Additional investment in various sectors will have an impact on production expansion and a growing economy and reduce income inequality. Barro (2000) stated that investment affects reducing income inequality between regions. Investment plays an active role in determining the rate of output growth and the amount of output (Arsyad, 2010). Investment is an important asset to develop a more advanced region. New investment in underdeveloped areas will increase the capacity of the regional economy to produce goods and services.

Road infrastructure is an important infrastructure in supporting land transportation to connect one area to another. It has an accessibility function to open up disadvantaged areas and spur more developed areas. The availability of adequate roads will ensure a faster and more efficient distribution of goods and services, and lowering income inequality between regions. This study is the same as what was done by Maryaningsih et al. (2014) that the road infrastructure reduces regional economic development inequality. The development of road infrastructure will ensure the efficient movement of goods and services, and increase the added value of the economy as well as become a factor driving regional productivity.

Regional financial policies are always directed at realizing an independent regional economy by adhering to the principles of economic democracy based on Pancasila and the 1945 Constitution. According to Elia et al (2020), regional development requires development financing that involves the development of fiscal activities, particularly allocation, distribution and stabilization, a bigger source of financing (Tangkilisan, 2013).

During the period of 2010 to 2017, economic growth showed a negative and significant effect on inequality in income distribution between regions. In line with increased economic growth, the inequality of income distribution between regions will decrease. This is in line with Yasa \& Arka (2015) that economic growth in a region can reduce income disparity between regions (Chen \& Groenewold, 2019).

\section{Direct and Indirect Effect}

This study also shows the direct and indirect effects of each variable on inequality in income distribution (Table 5). The indirect effect can be observed from the role of economic growth as a mediation for the effect of any variable on income inequality. As the findings have been presented, all variables have a significant effect on economic growth (Table 3). Meanwhile, economic growth also significantly affects income inequality (Table 4). This shows that economic growth can be a significant mediating variable or an indirect effect of economic growth in the working model.

PAD has an indirect effect on the inequality of income distribution between regions through economic growth. This mediation of economic growth increases the influence of PAD in reducing the inequality of income distribution between regions in regencies/cities in Bali Province.

Moreover, economic growth is proven to work to mediate the role of the government in the fields of education, health, investment, and infrastructure in reducing income inequality among regions in Bali province. Road infrastructure and investment flow will help increase the mobility of goods, services, and people. Road infrastructure as a link between regions will help spread economic activity. This will lead to the emergence of new economic growth points so that other regions will also grow and develop simultaneously in accordance with the potential of their respective regions. Banister \& Berechman (2001) stated that increasing transportation accessibility will reduce travel time and costs, increase mobility volumes and cause financial and allocative externalities which in turn lead to economic growth and spatial redistribution of economic activity. 
Table 5. Direct and Indorect Relationship between Variables

\begin{tabular}{lccc}
\hline Variable Relationship & $\begin{array}{c}\text { Direct } \\
\text { Effect }\end{array}$ & $\begin{array}{c}\text { Indirect } \\
\text { Effect }\end{array}$ & $\begin{array}{c}\text { Total } \\
\text { Effect }\end{array}$ \\
\hline PAD $\rightarrow$ Economic growth $\left(X_{1} \rightarrow Y_{1}\right)$ & 0,468 & - & 0,468 \\
PAD $\rightarrow$ Income inequality $\left(X_{1} \rightarrow Y_{2}\right)$ & $-1,111$ & $-0,245$ & $-1,356$ \\
Education Expenditure $\rightarrow$ Economic growth $\left(X_{2} \rightarrow Y_{1}\right)$ & 0,527 & - & 0,527 \\
Education Expenditure $\rightarrow$ Income inequality $\left(X_{2} \rightarrow Y_{2}\right)$ & $-0,436$ & $-0,276$ & $-0,712$ \\
Health Expenditure $\rightarrow$ Economic growth $\left(X_{3} \rightarrow Y_{1}\right)$ & 0,695 & - & $-0,695$ \\
Health Expenditure $\rightarrow$ Income inequality $\left(X_{3} \rightarrow Y_{2}\right)$ & $-0,449$ & $-0,364$ & $-0,813$ \\
Investment $\rightarrow$ Economic growth $\left(X_{4} \rightarrow Y_{1}\right)$ & 0,080 & - & 0,080 \\
Investment $\rightarrow$ Income inequality $\left(X_{4} \rightarrow Y_{2}\right)$ & $-0,384$ & $-0,042$ & $-0,426$ \\
Infrastructure $\rightarrow$ Economic growth $\left(X_{5} \rightarrow Y_{1}\right)$ & 0,259 & - & 0,259 \\
Infrastructure $\rightarrow$ Income inequality $\left(X_{5} \rightarrow Y_{2}\right)$ & $-0,359$ & $-0,136$ & $-0,495$ \\
Economic growth $\rightarrow$ Income inequality $\left(Y_{1} \rightarrow Y_{2}\right)$ & $-0,524$ & - & $-0,524$ \\
\hline
\end{tabular}

These findings indicate that all potentials in each region need to work optimally by coordinating economic, financial, investment, infrastructure, and human resources, to jointly plan for the creation of economic growth in each region. The allocation of resources in a balanced manner between regencies/cities will encourage higher economic growth so that it has an impact on reducing inequality between regions.

\section{Research Implication}

The government needs to work hard to increase PAD from a local resource and implement policies that make it easier for people to carry out economic activities, especially in the service sector such as hotels and restaurants, as well as manufacturing industries and agriculture that have significant economic contributions in regencies/cities in Bali Province.

Research shows that government spending on education encourages increased economic growth in regencies/cities in Bali Province. The education budget of 20 percent of the APBN and APBD is the realization of the government to improve education. A large budget for the education sector provides opportunities for everyone to be able to access education properly. Supervision needs to be carried out in an orderly manner to prevent budget leakage and to achieve better and evenly distributed targets for the quality of human resources.

The existence of a free education program financed or facilitated by the government will help the community to gain access to education services. Education should be able to produce quality human resources who have knowledge, understand technology, have adequate technical and life skills.
According to Schweke (2015), education will not only produce quality human resources but it can also foster a healthy business climate to support economic growth.

Government spending in the health sector provides opportunities for the community to get better health services to create healthier and more productive human resources. The quality of human resources can further create and develop economic activities to generate economic growth in the region (Rahmawati et al., 2020). Increasing and equalizing the quality of human resources in underdeveloped areas will spur the emergence and growth of innovation in underdeveloped areas so that they can catch up with more developed regions. Sachs (2002) states that health expenditure policies affect the welfare of present and future generations which in turn affects economic growth.

Investment is one element of the production that actively determines the level of output and can be a starting point for the success and sustainability of future development. Investment and strengthening of infrastructure will further increase the economic growth of regencies/cities in Bali Province. The investment climate will also be developed optimally when the quality of human resources and infrastructure is conditionally available. The tourismbased economy in Bali Province desperately needs the support of good road infrastructure that will help smooth the mobility of resources between regions. Road infrastructure as a link between production centers and marketing areas is very useful to improve the economy of a region. Furthermore, improving infrastructure will reduce the inequality of income distribution between regions in regencies/cities in Bali Province. 


\section{CONCLUSION AND SUGGESTION}

Locally-generated revenue, education expenditure, government spending on health, investment, and infrastructure have a positive effect on economic growth and inequality reduction of income distribution in regencies/cities in Bali Province. The research further shows that economic growth can work to mediate the role of the government in the fields of education, health, investment, and infrastructure in reducing income inequality among regions in Bali province. This study emphasizes local governments to cooperate and coordinate in planning to mobilize human resources, finance, investment, and infrastructure; to generate economic growth and reduce inequality between regions.

The research provides a suggestion that the government needs to increase local revenue from $P A D$, allocate funding for education and health, which reach all the population equally with the provision of adequate facilities and services. The government has also found breakthroughs to promote the investment climate in the region, as well as strengthen road infrastructure to access economic resources throughout the region.

\section{REFERENCES}

Aísa, R., \& Pueyo, F. (2006). Government health spending and growth in a model of endogenous longevity. Economics Letters. https://doi.org/10.1016/j.econlet.2005.08.003

Arsyad, L. (2010). Ekonomi Pembangunan, Edisi Ketiga. Yogyakarta: STIE YKPN. https://books.google.co.id/books/about/Ekonomi_ pembangunan.html?id=87rwHAAACAAJ

Banister, D., \& Berechman, Y. (2001). Transport investment and the promotion of economic growth. Journal of Transport Geography. https://doi.org/10.1016/S0966-6923(01)00013-8

Bappenas. (2010). Manajemen Pengaduan Masyarakat dalam Pelayanan Publik. Laporan Kajian. Retrieved from https://www.bappenas.go. id/files/4013/7637/9049/Manajemen_Pengaduan_ Masyarakat_Dalam_Pelayanan_Publik.pdf

Bappenas. (2014). Kajian Strategi Pengelolaan Perikanan Berkelanjutan. Kementerian PPN/Bapenas Direktorat Kelautan Dan Perikanan. Retrieved from https://www.bappenas.go.id/files/ 7614/4401/4206/Strategi_Pengelolaan_Perikanan _Berkelanjutan.pdf
Barro, R. J. (2000). Inequality and growth in a panel of countries. Journal of Economic Growth, 5(1), 532. https://doi.org/10.1023/A:1009850119329

Berg, A. G., \& Ostry, J. D. (2017). Inequality and Unsustainable Growth: Two Sides of the Same Coin? IMF Economic Review, 65(4), 792-815. https://doi.org/10.1057/s41308-017-0030-8

Bloom, D. E., \& Canning, D. (2008). Population Health and Economic Growth. Commission on Growth and Development, 1-25. Retrieved from http://siteresources.worldbank.org/EXTPREMNET/ Resources/489960-1338997241035/

Growth_Commission_Working_Paper_24_Populati on_Health_Economic_Growth.pdf

Bloom, D. E., Canning, D., \& Sevilla, J. (2004). The effect of health on economic growth: A production function approach. World Development, 32(1), 113. https://doi.org/10.1016/j.worlddev.2003.07.002

Bratakusumah, D. S. 2001. Otonomi Penyelenggaran Pemerintah Daerah. Jakarta: PT Gramedia. https://books.google.co.id/books?id=RGCnDB7w O1EC

Cervellati, M., \& Sunde, U. (2011). Life expectancy and economic growth: The role of the demographic transition. Journal of Economic Growth, 16(2), 99133. https://doi.org/10.1007/s10887-011-9065-2

Chambers, D. (2010). Does a rising tide raise all ships? The impact of growth on inequality. Applied Economics Letters, 17(6), 581-586. https://doi.org/10.1080/13504850802046971

Chen, A., \& Groenewold, N. (2019). Macroeconomic shocks in China: Do the distributional effects depend on the regional source? Annals of Regional Science, 62(1), 69-97. https://doi.org/10.1007/s00168-018-0885-2

Cingano, F. (2014). Trends in Income Inequality and its Impact on Economic Growth. OECD Social, Employment, and Migration Working Papers, (163), 0_1,5-59. https://doi.org/ $10.1787 / 5 j x r j n c w \times v 6 j$-en

Danawati, S., Bendesa, I. K., \& Utama, M. S. (2016). Pengaruh pengeluaran pemerintah dan investasi terhadap kesempatan kerja, pertumbuhan ekonomi serta ketimpangan pendapatan Kabupaten/Kota Di Provinsi Bali. E-Jurnal Ekonomi dan Bisnis Univeristas Udayana, 5(7), 2123-2160. Retrieved from https://ojs.unud.ac.id/index.php/ EEB/article/view/13030

Elia, A., Yulianto, Y., Tiawon, H., Sustiyah, S., \& Indrajaya, K. (2020). Government expenditure and poverty reduction in the proliferation of new 
administrative areas of Central Kalimantan, Indonesia. Journal of Socioeconomics and Development, 3(2), 145-155. https://doi.org/10.31328/jsed.v3i2.1410

Enceng, I, Lestyodono, B., \& Purwaningdyah, M. W. (2014). Desentralisasi fiskal penerimaan keuangan daerah. Jurnal Ilmu Administrasi Negara, 12(1), 61-73. Retrieved from https://ejournal.unri.ac. id/index.php/JIANA/article/view/904

Fawaz, F., Rahnama, M., \& Valcarcel, V. J. (2014). A refinement of the relationship between economic growth and income inequality. Applied Economics, 46(27), 3351-3361. https://doi.org/10.1080/00036846.2014.929624

Forbes, K. J. (2000). A reassessment of the relationship between inequality and growth. American Economic Review, 90(4), 869-887. https://doi.org/10.1257/aer.90.4.869

Garcia, J. G., \& Soelistianingsih, L. (1998). Why do differences in provincial incomes persist in Indonesia? Bulletin of Indonesian Economic Studies, 34(1), 95-120. https://doi.org/10.1080/00074919812331337290

Gujarati, D. N. (2004). Basic Econometrics. New York. McGraw Hill Book Company. https://doi.org/10.1126/science.1186874

Hong Vo, D., Van Nguyen, P., Minh Nguyen, H., The Vo, A., \& Cong Nguyen, T. (2020). Derivatives market and economic growth nexus: Policy implications for emerging markets. North American Journal of Economics and Finance, 54. https://doi.org/10.1016/j.najef.2018.10.014

Huang, H. C., Fang, W. S., Miller, S. M., \& Yeh, C. C. (2015). The effect of growth volatility on income inequality. Economic Modelling, 45, 212-222. https://doi.org/10.1016/j.econmod.2014.11.020

Kuznets, S. (1955). Growth and income inequality. The American Economic Review. 45(1). 1-28. Retrieved from https://www.jstor.org/stable/1811581

Li, H., \& Zou, H. F. (1998). Income inequality is not harmful for growth: theory and evidence. Review of Development Economics, 2(3), 318-334. https://doi.org/10.1111/1467-9361.00045

Lopez-Casasnovas, G., Rivera, B., \& Currais, L. (2005). Health and Economic Growth: Findings and Policy Implications. World Economy (Vol. 30, pp. 533534). Wiley/Blackwell (10.1111). Retrieved from http://doi.wiley.com/10.1111/j.14679701.2007.1003_2.x

Lundberg, M., \& Squire, L. (2003). The simultaneous evolution of growth and inequality. Economic
Journal, 113(487), 326-344. https://doi.org/10.1111/1468-0297.00127

Madsen, J. B., Islam, M. R., \& Doucouliagos, H. (2018). Inequality, financial development and economic growth in the OECD, 1870-2011. European Economic Review, 101, 605-624. https://doi.org/10.1016/j.euroecorev.2017.11.004

Majumdar, S., \& Partridge, M. D. (2009). Impact of economic growth on income inequality: a regional perspective. Agricultural and Applied Economics Association 2009 AAEA and ACCI Joint Annual Meeting. https://doi.org/10.22004/ag.econ.49270

Maryaningsih, N., Hermansyah, O., \& Savitri, M. (2014). Pengaruh infrastruktur terhadap pertumbuhan ekonomi Indonesia. Buletin Ekonomi Moneter dan Perbankan, 17(1), 62-98. https://doi.org/10.21098/bemp.v17i1.44

Nissim, B. D. (2007). Economic growth and its effect on income distribution. Journal of Economic Studies, 34(1), 42-58. https://doi.org/10.1108/01443580710717219

Nurhuda, R. (2013). Analisis ketimpangan pembangunan (Studi di Provinsi Jawa Timur Tahun 2005-2011). Jurnal Administrasi Publik Mahasiswa Universitas Brawijaya, 1(4), 110-119. Retrieved from http://administrasipublik.studentjournal. ub.ac.id/index.php/jap/article/view/134

Ospina, M. (2014). The Effect of Social Spending on Income Inequality: An analysis for Latin American countries. Center for Research in Economics and Finance (CIEF), Working Papers, No. 10-03. Retrieved from https://papers.ssrn.com/sol3/ papers.cfm?abstract_id $=2427510$

Rahmawati, F., Ananda, F. P., \& Narmaditya, B. S. (2020). Socio-economic indicators and income inequality: Lesson from West Java in Indonesia. Scientific Papers of the University of Pardubice, Series D: Faculty of Economics and Administration, 28(3). https://doi.org/10.46585/sp28031114

Rubin, A., \& Segal, D. (2015). The effects of economic growth on income inequality in the US. Journal of Macroeconomics, 45, 258-273. https://doi.org/10.1016/j.jmacro.2015.05.007.

Sachs, J. D. (2002). Macroeconomics and health: investing in health for economic development. Revista Panamericana de Salud Pública, 12(2), 143-144. https://doi.org/10.1590/s102049892002000800017

Samuelson, P. A., \& Nordhaus, W. D. (2006). Cap. 1: Los fundamentos de la economía. In Economía. Retrieved from http://spain-s3-mhe-prod.s3- 
website-eu-west-1.amazonaws.com/bcv/guide/ capitulo/8448151542.pdf

Schweke, W. (2015). Connecting asset building and community development. In Reengineering Community Development for the 21st Century (pp. 143-156). Taylor and Francis. https://doi.org/10.4324/9781315701240-16

Tambunan, T. (2007). Daya saing Indonesia dalam menarik investasi asing. In Seminar Bank Indonesia (pp. 1-21). Retrieved from https://docplayer.info/32517599-Daya-saingindonesia-dalam-menarik-investasi-asing-1.html

Tangkilisan, Y. B. (2013). Indonesia dan masalah perbatasan: Beberapa masalah dalam perkembangan daerah tapal batas sebagai bagian perekonomian nasional dari perspektif sejarah. Susurgalur: Jurnal Kajian Sejarah \& Pendidikan Sejarah, $1(1)$, 85-86.
Wahiba, N. F., \& Weriemmi, M. El. (2014). The relationship between economic growth and income inequality. International Journal of Economics and Financial Issues, 4(1), 135-143. Retrieved from http://www.econjournals.com/index.php/ijefi/artic le/view/657

Yasa, I. K. O. A., \& Arka, S. (2015). Pengaruh pertumbuhan ekonomi dan disparitas pendapatan antardaerah terhadap kesejahteraan masyarakat Provinsi Bali. E-Jurnal Ekonomi Pembangunan Universitas Udaya, 4(2), 129-137. https://doi.org/10.24843/JEKT.2015.v08.i01.p07.

Zulyanto, A. (2010). Pengaruh desentralisasi fiskal terhadap pertumbuhan ekonomi di Provinsi Bengkulu. Jurnal Ekonom, 17(3), 1-122. Retrieved from http://ejournal.unp.ac.id/index.php/ ekosains/ article/view/3465

https://doi.org/10.2121/susurgalur.v1i1.58 